\title{
CATCH COMPOSITION, BIOMASS, AND DISTRIBUTION OF CEPHALOPHODS IN THE INDIAN OCEAN OF SOUTHERN JAVA AND WESTERN SUMATERA
}

\author{
Awwaluddin"), Ali Suman"), Fayakun Satria"), and Suprapto")
}

\begin{abstract}
An exploratory trawling to obtain data on the catch rate, species composition, and distribution of the deep sea cephalophods in the Indian Ocean of southern Java and eastern Sumatera using the RV Baruna Jaya IV was carried out during May 2 to July 7 year 2005. The magnitude of biomass was estimated using the swept area method. During the period, in the southern Java area there were 38 species of chepalopods belonging to the 16 families, while in the western Sumatera were 20 species of the 12 families. Catch rate of cephaplopod resources in the southern Java during the survey period was about $175 \mathrm{~kg}$ per hr, the amount of about $1.5 \%$ of the total catch rate of deep sea fish resources. The total catch rate in the western Sumatera of $44 \mathrm{~kg}$ per hr was smaller, but the percentage of $2.1 \%$ was higher compared with the catch rate in the southern Java. The family Loliginidae provided the most dominated cephalopods with the catch rate of about $80 \mathrm{~kg}$ per hr, the amount of about $46 \%$ of the total catch rate of deep sea fish resources in the southern Java area. In the western Sumatera the family Mastigoteuthidae represented the most dominated cephalopods with the catch rate of about $18 \mathrm{~kg}$, or about $41 \%$ of the total catch rate of fish resources. The estimated stock density of cephalopods resources in the southern Java was about $112 \mathrm{~kg} \mathrm{~km}^{-2}$, with the annual potential yield of about 617 tonnes. High density of cephalopods in this area was found in the waters of the southern part off East Java, in the western part and eastern part off Cilacap. The estimated stock density in the western Sumatera was about $29 \mathrm{~kg} \mathrm{~km}^{-2}$ with the annual potential yield of about 145 tonnes. The distribution of cephalopod resources in this area in term of density was likely forming a large schooling occoured in the waters around Simeuleu Island (area S-4), while the density in the western off Bengkulu and Banda Aceh was likely lower compared with the Simeuleu area. The higher density of cephalopod resources in the southern Java area was likely occurred in the deeper waters at the depth range of 750 to $1,000 \mathrm{~m}$, while in the western Sumatera was found at the depth range of 500 to $750 \mathrm{~m}$.
\end{abstract}

KEYWORDS: cephalopod, catch rate, stock density, southern Java, western Sumatera

\section{INTRODUCTION}

Cephalophods resources in the coastal waters of the Indian Ocean consist of squids, cuttle fish, and octopuses have been exploited for years. The southern waters of Nusa Tenggara, with the Alas strait for example, provide the most widely known squid fisheries area since the sixthies. The squid resources provide the most economically important non fish resources although their statistical production was relatively lower compared with the fish production. Ecologically, the squids resources provide an opportunist species (Rodhouse, 2001), where squids population will tend to increase when other fish species decrease. This phenomenon has been occurred in the gulf of Thailand, where the decreasing trend in the demersal fish stock has been followed by the increasing trend of squids population (Pope, 1979). With this phenomenon it is likely that the squids fisheries exploit an unstable resources. Continuous high rate of exploitation of this resource will undoubtedly lead to the decreasing trend of squids resource population.

In general, the squid nets provide fishing gear used by the squid fishers along the coastal waters of the Indian Ocean. The squid fishing usually is carried out during the night with the light as the aggregating devices. This low cost and simple fishing technology is widely used leading to the higher pressure of exploitation of the resources.

Information on deep sea squid resources is very limited. An exploratory trawling on the squid resources was carried out in the framework of species inventory, stock analysis including density, and biomass estimation and distribution of the most economically important cephalopods in both vertical and horizontal. Results of the exploratory trawling of the deep sea resources in the Indian Ocean southern Java and western Sumatera provide important information needed for the commercial exploitation and development of fish resources.

\section{MATERIALS AND METHODS}

\section{Survey Areas}

Data analyzed were parts of the results of exploratory trawling using the RV Baruna Jaya IV, carried out in the framework of The Japan-

\footnotetext{
Research Institute for Marine Fisheries, Muara Baru-Jakarta
} 
Indonesia Deep Sea Fisheries Resources Joint Exploration Marine Research 2004, with one of the main objeotives to study the catch per unit area as an index of abundance of the deep sea demersal fish resources in the Indian Ocean Southern Java and Western Sumatera (Anonymous, 2005; 2006). These exploratory trawlings were carried during
May to July 2005. The trawling activities covered the survey areas from $108^{\circ}$ to $113^{\circ} \mathrm{E}$ of the southern Java and moved to the western part of Sumatera started from around Enggano northward to the tip of Sumatera Island, the waters of western off Banda Aceh. The fishing gear used was the trawl special design for the deep water trawling

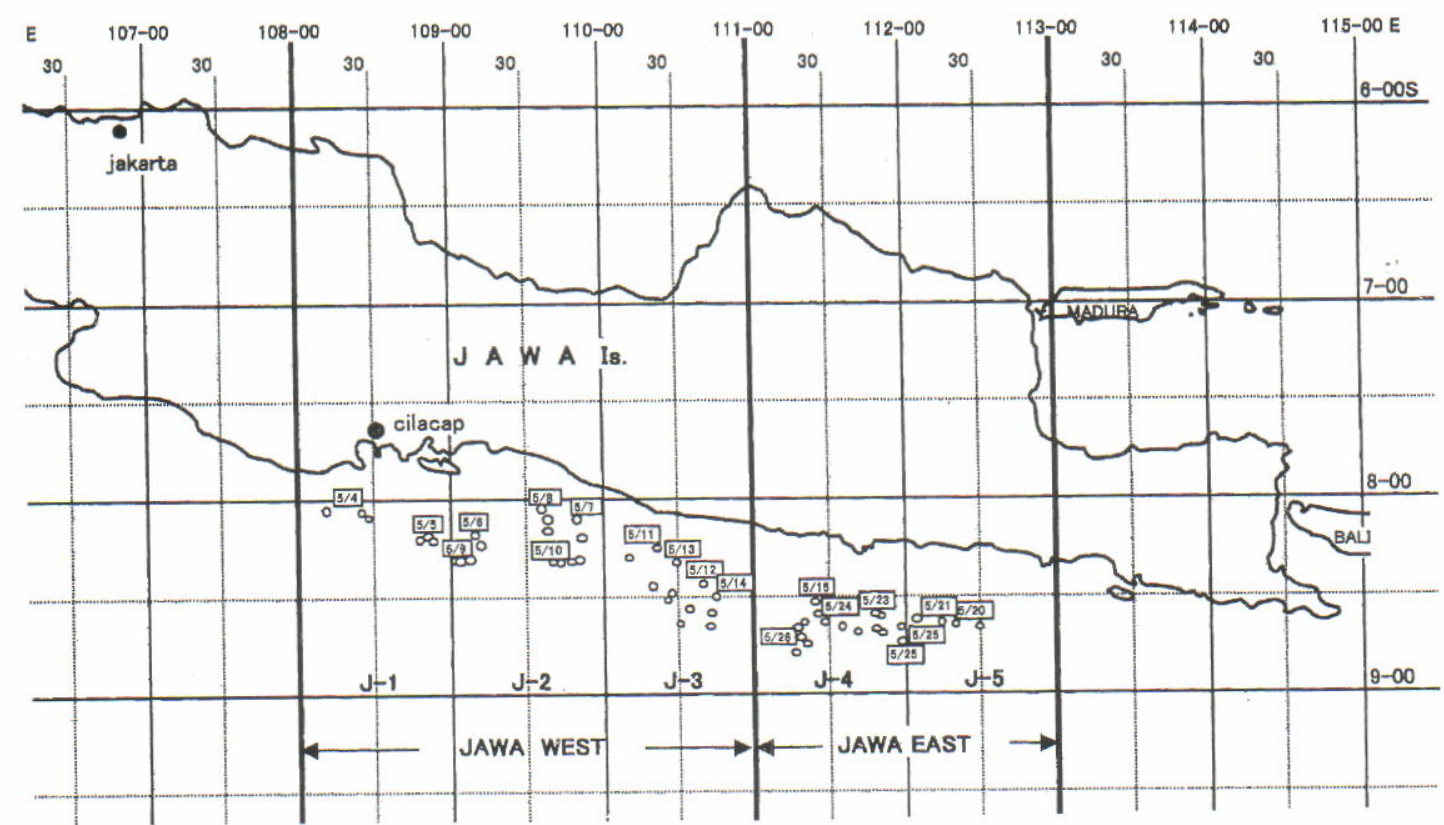

Figure 1. Fishing stations (divided into 5 area) in Southern Java waters.

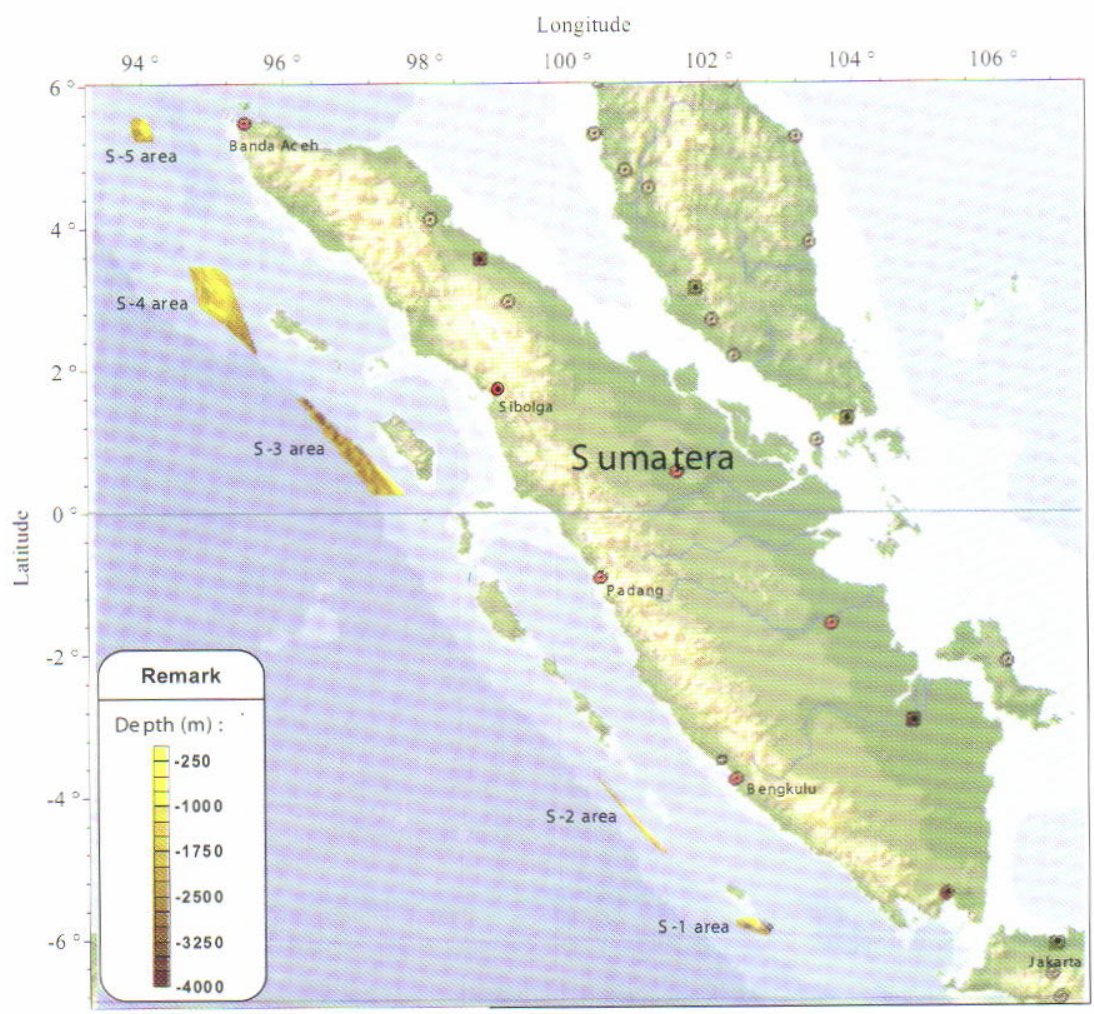

Figure 2. Fishing stations in western Sumatera. 
purposes. The survey locations are depicted in Figure 1 and 2. The catch obtained were sorted into species, genus and family, and weighted.

The survey area of the southern Java was divided into 5 areas. Area $\mathrm{J}-1$ and $\mathrm{J}-2$ are located around the western and the eastern part of Cilacap. Area J-3 is located approximately around the southern waters of Parangtritis, while Area J-4 and $\mathrm{J}-5$ are in the southern part of East Java (Figure 1). In these areas, 52 trawl fishing stations had been completed. In the western Sumatera, the survey area were divided into 4 sub areas. Area S-1 was located around Enggano Island, area S-2 approximately in the western part off Bengkulu. Area S-3 the area around Siberut Island in which the condition of the sea bottom was not permitted for the fishing operation and therefore all the planned fishing stations were cancelled. Area S-4 was located around Simeuleu Island, and area S-5 was approximately located in the western part off Banda Aceh (Figure 2). In the western Sumatera waters, a total of 50 fishing stations was completed.

\section{Data Analysis}

Trawling activities were carried out during the day time ( 08.00 to $18.00 \mathrm{hrs}$ ). By using the swept. area method the stock density of fish resources was estimated following the procedure explained in Sparre \& Venema (1992), as follows:

$$
D=(1 / a . n) \times(c / f)
$$

a. $n=t \times v \times h \times e \times 1.852 \times 0.001$

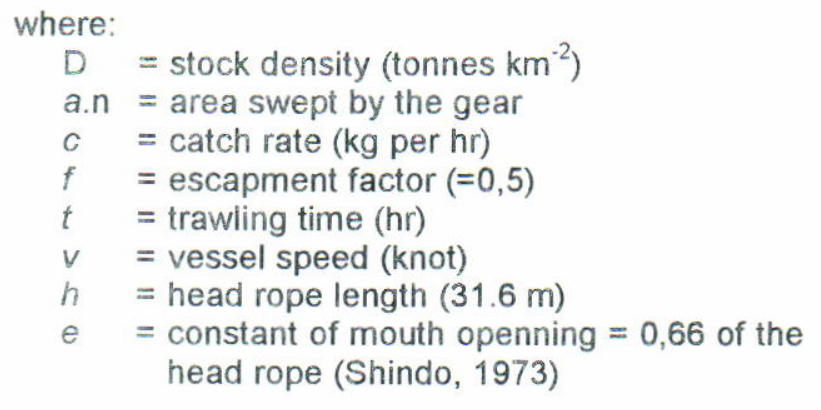

\section{RESULTS AND DISCUSSION}

\section{Species, Catch Rate, and Catch Composition}

Based on catch observations in the whole areas of survey, a total of 45 according to deep sea cephalopods species was identified Carpenter \& Niem (1998). In the southern Java, these cephalophods consisted of 38 species belonging to the 16 families, while in the western Sumatera there were 20 species belonging the 12 families. The number of cephalopods species in southern Java was almost twice higher compared with that in the western Sumatera counterpart, while the number of families in the southern Java was 25\% higher than that in the western Sumatera. From this point of view it seems that the cephalopods resources in the southern Java were more diverse.

Catch rate as an index of abundance (Gulland, 1983) of cephalopods resources in the southern Java was about $175 \mathrm{~kg}$ per hr, the amount of around $1.5 \%$ from the total catch rate of the deep sea resources in this area. Cephalopods catch rate in the western Sumatera of only about $44 \mathrm{~kg}$ per $\mathrm{hr}$ was much lower, however, for the fish community analysis, as the total catch rate of fish resources in this area was also low, the percentage of cephalopods in the western Sumatera of $2.1 \%$ was almost 1.5 times higher.

The cephalophods catches in southern Java were dominated by the family Loliginidae with the catch rate reached to about $80 \mathrm{~kg}$ per hr or about $46 \%$ of the total cephalophods catches. The second most dominant families were Vampyroteuthidae and Mastigoteuthidae with the catch rate of $25 \mathrm{~kg}(14.3 \%)$ respectively, while other families were less than $10 \%$ :

Similar with the cephalopods catches in the southern Java, in term of fish community the most dominated family of more than $40 \%$ of the total catch rate in the western Sumatera was the family Mastigoteuthidae, with the catch rate of about $18 \mathrm{~kg}$ per hr. Other dominant cephalopod families were occoupied by the Vampyroteuthidae and Histioteuthidae with the respective percentage of about 25.4 and $17.6 \%$. Detail of catch and species composition of cephalopod are presented in Table 1.

\section{Stock Density and Potential Yield}

The availability of data and information on the stock density of fish resources in a certain area provides one of the basic aspects needed for the rational exploitation and development. The stock density of cephalopod resources in the southern Java of about $112 \mathrm{~kg} \mathrm{~km}^{-2}$ was higher than in the western Sumatera of only $29 \mathrm{~kg} \mathrm{~km}^{-2}$. Based on these figures, the estimated annual potential yield in the southern Java and western Sumatera were about 617 tonnes and 145 tonnes respectively (Table 2). It is probably that the annual potential yield of the deep sea cephalopod resources in the Indian Ocean seems to be relatively little amount. This small amount of the estimated yield was 
Table 1. Catch rate and catch composition of Cephalophods in southern Java and western Sumatera

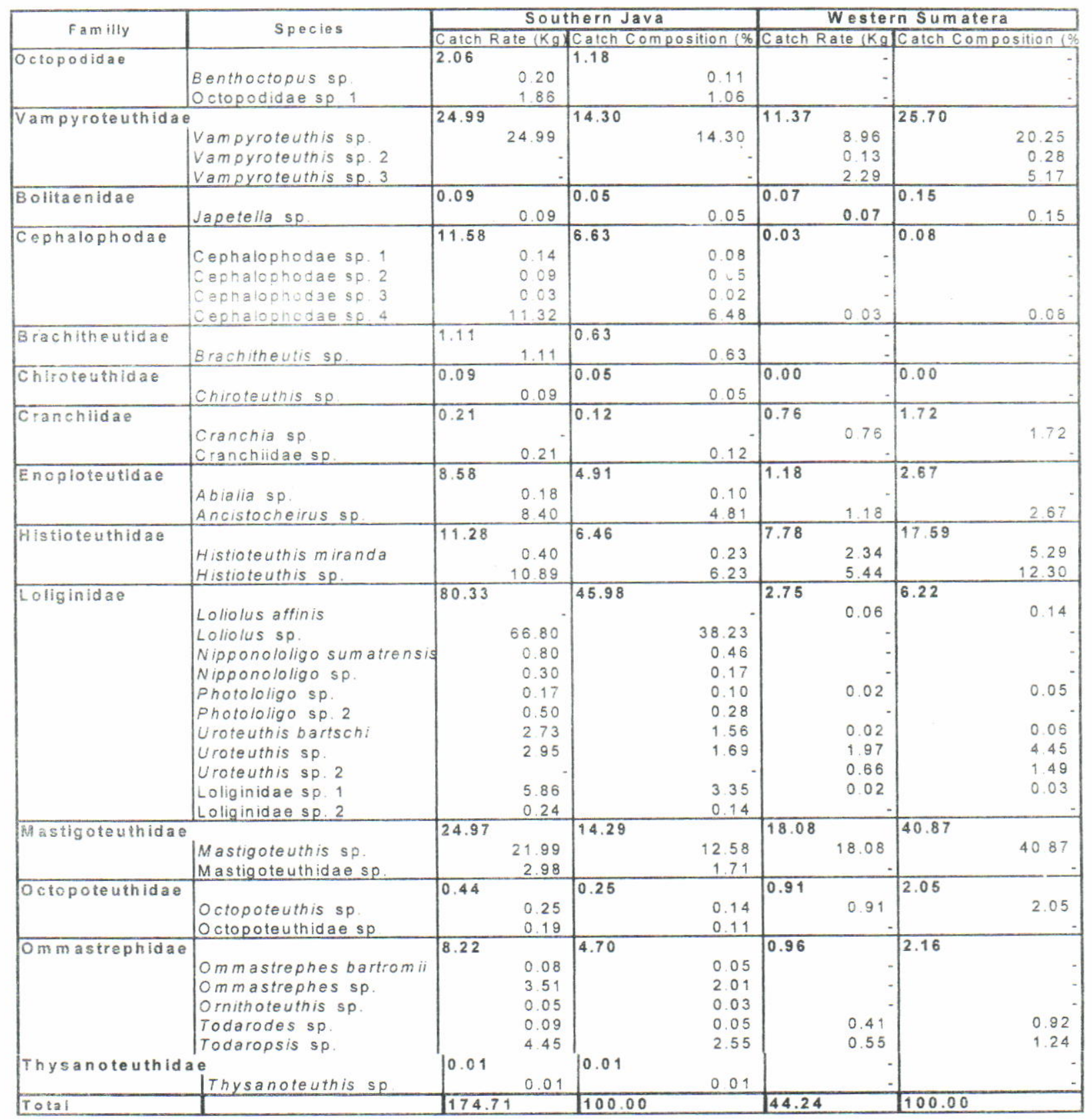

Table 2. Stock density and potential yield of cephalophods in southern Java and western Sumatera

\begin{tabular}{lcc}
\hline \multicolumn{1}{c}{ Parameter } & Southern Java & Western Sumatera \\
\hline Total Catch-rate $(\mathrm{kg}$ per hr) & 174.71 & 44.24 \\
Average $(\mathrm{kg}$ per $\mathrm{hr})$ & 3.36 & 0.88 \\
Area Swept by the gear $\left(\mathrm{km}^{2}\right)$ & 0.06 & 0.06 \\
Estimated stock density $\left(\mathrm{kg} \mathrm{km}^{-2}\right)$ & 111.99 & 29.49 \\
Estimated bottom area $\left(\mathrm{km}^{2}\right)$ & 11.019 & 9.865 \\
Biomass (tonnes) & $1,234.06$ & 290.95 \\
Annual Potential yield (tonnes) & 617.03 & 145.48 \\
\hline
\end{tabular}




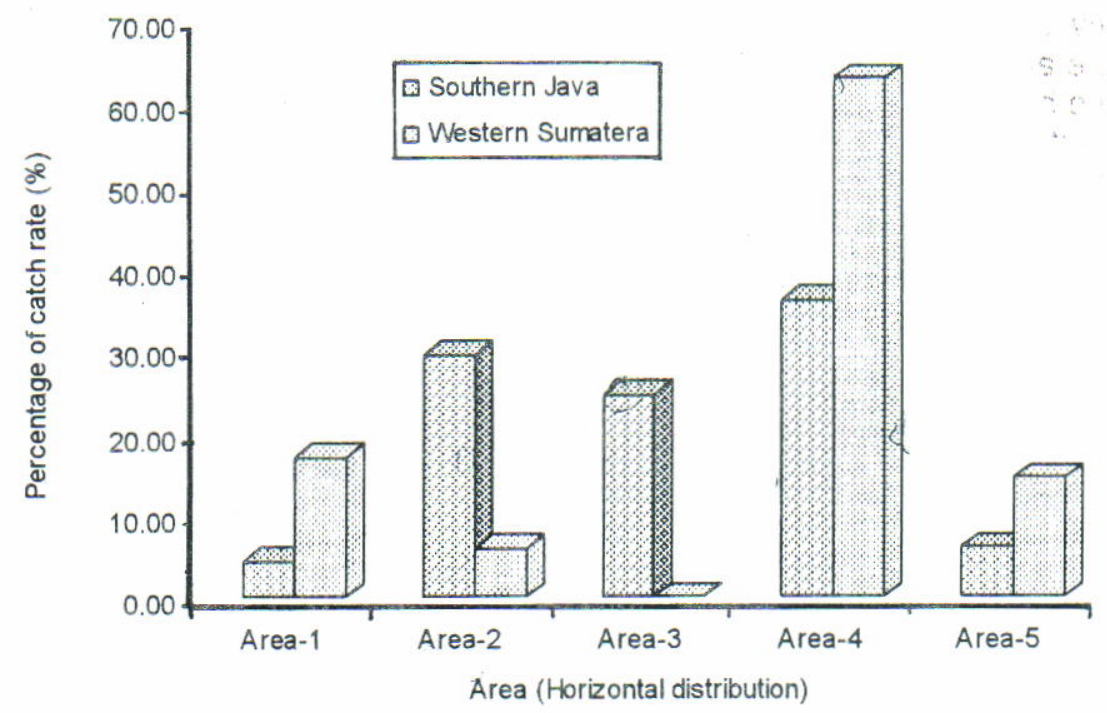

Figure 3. Horizontal distribution (by area) of cephalophods in Indian Ocean.

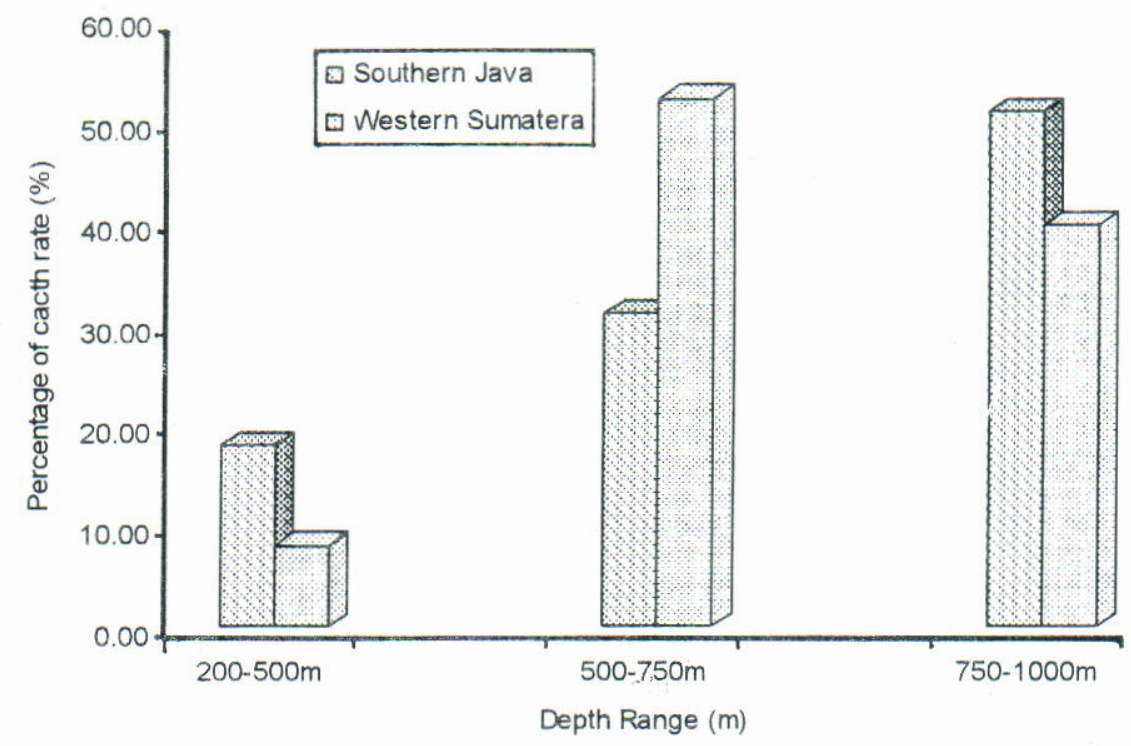

Figure 4. Vertical distribution (by depth) of cephalophods in Indian Ocean.

probably due to either some operational aspect of fishing activities such as fishing time. As it was already stated earlier that fishing gear used was the fish trawl which is not tergetted on squid, while the trawling activities were carried out only during the day time. Other reason might be related to the behaviour of the squid as an opportunistics species. As it was happened with the coastal shallow squid resources in the Alas Strait, West Nusa Tenggara Province. According to the fishers in Tanjung Luar it has been disappeared during the year 2000, while at the same time the small size of the species was reported booming in the area of Sape Strait, eventhough this was again disappeared in the following year. It was recently reported by the squid fishers in Tanjung Luar (2004) that the abundance squid resources was in the area of Eastern Sumba of the East Nusa Tenggara Province (Badrudin et al., 2004).

\section{Distribution of Cephalophods}

Horizontal distributions of cephalophods resources in the Indian Ocean are presented in Figure 3 . In the southern Java, cephalopod resources were widely distributed along the area 2 , 3 , and 4 , the area from around Cilacap to the eastern part of the southern waters of East Java. High occurrence of the cephalophods distribution was found in area 4, the area around the southern 
part of East Java, followed by the area 2, of the western part of Cilacap and the area 3 , the area of the eastern part of Cilacap. The highest occurrence of cephalopod resources in western Sumatera was found in the area around Simeuleu Island (area S4). The second high occurrence was found in the western area off Bengkulu, followed by the western part off Banda Aceh.

The vertical distribution of cephalophods resources was arranged to cover the three depth zone of, i.e, 200 to $500 \mathrm{~m}, 500$ to $750 \mathrm{~m}$, and 750 to $1,000 \mathrm{~m}$. It seems that a similar distribution pattern of the cephalopod occurred in the southern Java and the western Sumatera. In both area of southern Java and western Sumatera the cephalophod resources tend to increase toward the deeper waters (Figure 4), with some light differences. The highest occurrence of cephalopod distribution in the southern Java was found in the depth zone of 750 to $1,000 \mathrm{~m}$, while in the western Sumatera area was found in the shallower waters of the depth zone 500 to $750 \mathrm{~m}$.

\section{CONCLUSION}

During the survey period, in the southern Java area there were 38 species of chepalopods belonging to the 16 families, while in the western Sumatera were 20 species of the 12 families.

Catch rate of cephaplopod resources in the southern Java was about $175 \mathrm{~kg}$ per hr, the amount of about $1.5 \%$ of the total catch rate of deep sea fish resources. The total catch rate in the western Sumatera of $44 \mathrm{~kg}$ per $\mathrm{hr}$ was smaller, but the percentage of $2.1 \%$ was higher compared with the catch rate in the southern Java.

The family Loliginidae provided the most dominated cephalopods with the catch rate of about $80 \mathrm{~kg} \mathrm{per} \mathrm{hr}$, the amount of about $46 \%$ of the total catch rate of deep sea fish resources in the southern Java area. In the western Sumatera the family Mastigoteuthidae represented the most dominated cephalopods with the catch rate of about $18 \mathrm{~kg}$, or about $41 \%$ of the total catch rate of fish resources.

The estimated stock density of cephalopods resources in the southern Java was about $112 \mathrm{~kg}$ $\mathrm{km}^{-2}$, with the annual potential yield of about 617 tonnes. High density of cephalopods in this area was found in the waters of the southern part off East Java, in the western part and eastern part off Cilacap. The estimated stock density in the western Sumatera was about $29 \mathrm{~kg} \mathrm{~km}^{-2}$ with the annual potential yield of about 145 tonnes.
The distribution of cephalopod resources in this area in term of density was likely forming a large schooling found in the waters around Simeuleu Island (Area S-4), while the density in the western off Bengkulu and Banda Aceh was likely lower compared with the Simeuleu area. The higher density of cephalopod resources in the southern Java area might be occurred in the deeper waters at the depth zone of 750 to $1,000 \mathrm{~m}$, while in the western Sumatera was occurred in the shallower waters at thie depth zone of 500 to $750 \mathrm{~m}$.

\section{REFERENCES}

Anonymous. 2005. The Japan-Indonesia deep sea fishery resources joint exploration project (Report of 2004 Field Survey). OFCF-RIMF. 54 p.

Anonymous. 2006. The Japan-Indonesia deep sea fishery resources joint exploration project. November. 2005. Project Report. OFCF-RIMF. $151 \mathrm{p}$.

Badrudin, A. Suman, S. T. Hartati, I. S. Wahyuni, T. Hariati, B. Sumiono, T. Ernawati, S. Bahar, \& A. Gunawan. 2004. Research on the fish stock abundance index in the waters of Indian Ocean (Western Sumatera, Southern Java and BaliNusatenggara). Final Technical Report. RIMF. (In Indonesian). 205 p.

Carpenter, K. E. \& V. H. Niem (Eds). 1998. FAO Identification guide for fishing purposes. The living marine resources of the Western Central Pacific. Vol.2. Cephalopods, Crustaceans, Holoturians, and Sharks. FAO Rome.

Gulland, J. A. 1983. Fish stock assessment: A manual of basic methods. FAOMiley series on food and agriculture. $223 p$.

Pope, J. G. 1979. Stock assessment in multispecies fisheries, with special reference to the trawl fishery in he Gulf of Thailand. SCS/DEV/79/19. FAO UN. Manila. Philippines. $106 \mathrm{p}$.

Rodhouse, P. G. 2001. Managing and forecasting squid fisheries in variable environments. Fisheries Research. 54 (1): 3-8 p.

Sparre, P. \& S. C.Venema. (992. Introduction to tropical fish stock assesment. Part I. Manual. FAO Fish. Tech. Pap. No.306/1.

Shindo, S. 1973. General review of the trawl fishery and the demersal fish stock of the South China Sea. FAO Fish.Tech.Pap. (120): 49 p. 